\title{
EFFECT OF SPRINKLER IRRIGATION MANAGEMENT AND STRAW MULCH ON YIELD, WATER CONSUMPTION AND CROP COEFFICIENT OF PEANUT IN SANDY SOIL
}

\author{
ZAYTON, A.M., A.E. GUIRGUIS and KH. A. ALLAM
}

Agric. Eng. Res. Inst., ARC, Dokki, Giza

(Manuscript received 18 February 2014)

\begin{abstract}
Field experiments were conducted at El-Bustan Agricultural Research Station, in summer season of 2013 on peanut (Arachis hypogaea L.) variety Giza 5, to study the effect of sprinkler irrigation management and the application of rice straw mulch on yield, quality, water consumptive use and crop coefficient of peanut in sandy soil. Two irrigation treatments, $\left(\mathrm{I}_{3}\right)$ and $\left(\mathrm{I}_{5}\right)$ were imposed based on the soil water depletion to bring the soil water deficit to the field capacity at two irrigation intervals of 3 and 5 days. Mulching treatments were applied randomly during the 3-leaf growth stage for one half of the experimental area (M) at a rate of about $500 \mathrm{~g} / \mathrm{m}^{2}$, while the other half remained bare (non-mulched, $M_{0}$ ). The experimental design was split- plot with three replications and consisted of irrigation treatments in the main plots, mulching and non-mulching treatments as subplots. The results revealed that, higher yield and better crop growth were observed in the mulched plots as compared to nonmulched plots under the same irrigation treatments. Also, the effect of $\mathrm{I}_{3}$ treatment was more pronounced than the effect of $\mathrm{I}_{5}$ treatments. The average values of maximum plant length, No. of pods/plant, pods weight/plant, total Bio-mass, 100 kernels weight ,total pods yield and total kernels yield, were $65.00 \mathrm{~cm}, 39.45,53.20 \mathrm{~g} ., 4012.05 \mathrm{~kg} / \mathrm{fed}, 67.10 \mathrm{~g}$, $1658.80 \mathrm{~kg} / \mathrm{fed}$ and $1176.00 \mathrm{~kg} / \mathrm{fed}$, respectively observed with $\mathrm{I}_{3} \mathrm{M}$ treatment. An increase in the tested quality parameters such as shelling percent, protein and oil percentage, of $8.9,4.40$ and $2.13 \%$, respectively were obtained with $\mathrm{I}_{3} \mathrm{M}$ treatment as compared to the control treatment $\left(\mathrm{I}_{3} \mathrm{M}_{\mathrm{O}}\right)$. The computed $\mathrm{ET}_{0}$ value in course of the peanut growth season was $752.25 \mathrm{~mm} . \mathrm{I}_{3} \mathrm{M}_{\mathrm{O}}$ treatment had the maximum $\mathrm{ET}_{\mathrm{C}}$ and applied irrigation water (AIW) values of 2415.0 and $2952.60 \mathrm{~m}^{3} / \mathrm{fed}$, respectively. Applying rice straw mulch conserved irrigation water by about 14.37 and $21.62 \%$ with $I_{3}$ and $I_{5}$ treatments, respectively. WUE ranged from 0.60 with $\mathrm{I}_{3} \mathrm{M}$ and $\mathrm{I}_{5} \mathrm{M}$ to $0.36 \mathrm{~kg} / \mathrm{m}^{3}$ with $\mathrm{I}_{5} \mathrm{M}_{\mathrm{O}}$ treatment, meanwhile, $\mathrm{I}_{5} \mathrm{M}$ and $\mathrm{I}_{3} \mathrm{M}$ treatments had the maximum IWUE values of 0.48 and $0.47 \mathrm{~kg} / \mathrm{m}^{3}$, respectively. The maximum crop coefficient $\left(\mathrm{K}_{\mathrm{C}}\right)$ value of 0.88 occurred during July, which was less than the generic value listed in FAO-33and-56 by about 16.2 and $10.2 \%$, respectively, however the average $K_{c}$ values of peanut at El-Bustan area of 0.73 was close to FAO-33 and-56 listed values. These results showed that precise management of the available soil moisture content in the course of the growing season, and accurate estimation of $\mathrm{ET}_{\mathrm{C}}$ as well as, developing site and cultivar specific $\mathrm{K}_{\mathrm{C}}$ value can be effective way for appropriate irrigation scheduling and water allocation, saving water, maximizing yield and consequently optimizing the economic return.
\end{abstract}

Keywords: Peanut, Sprinkler Irrigation, Mulch, Irrigation Management, Crop coefficient. 


\section{INTRODUCTION}

Field management practices are the most influenced factors affecting crop yield particularly in irrigated agriculture in arid and semi-arid regions. The productivity of sandy soils are limited by higher infiltration rate, high evaporation, low fertility level, low water holding capacity and low organic matter content .Peanut (Arachis hypogaea L.) is considered one of the most important edible oil crops grown in Egypt. The main growing areas concentrated in the north of the country representing newly reclaimed desert areas, and in the east and west of the Nile delta. It is either grown for its nut, oil and its green leafy hay for feeding livestock. Peanut seeds are characterized by their high oil content (about 50\%), which is utilized in different industries, besides they contain about $26-28 \%$ protein, about $20 \%$ carbohydrates and about $5 \%$ fiber and ashes. There are some critical points characterized peanut growth stages, flowering and pod filling growth stages are very sensitive to soil water availability compared with early and vegetative and late maturity growth stages. Also, soil temperature, lower than $18^{\circ} \mathrm{C}$ reduces germination and crop growth and temperature higher than $37^{\circ} \mathrm{C}$ during pod development restricts pod and kernel growth resulting in lower pod yield (Reddy et al., 2003). Raskar and Bhoi (2003) reported that the practice of mulching is widely used as a management tool in many parts of the world. It dampens the influence of environmental factors on soil by increasing soil temperature controlling diurnal/seasonal fluctuations in soil temperature. Plastic or straw mulch may efficiently improve the microclimate and growth conditions by promoting plant transpiration at the expense of evaporation from the soil. Ghosh et al., (2006) reported that straw mulch ( wheat or paddy) produced more pod and haulm yields of peanut than polythene mulch ( black or transparent) and no mulch treatment because of favorable soil water and soil temperature, earlier seedling emergences, more flower and mature pods numbers, lower bulk density and less weeds. Crop yield and water use efficiency (WUE) have been reported to be increased by mulching treatments. Irrigation management is necessary for field crops. Increases water use efficiency (WUE) of field crops is possible through proper irrigation scheduling and water management avoiding any soil moisture stress and critical growth stages. Improper irrigation management not only causes variation in crop yield but also wastes scarce and valuable water resources. Delayed irrigation, particularly when the crop is sensitive to water stress, could affect yield, which cannot compensated for by subsequent over-watering. Sprinkler irrigation offers advantage by light and frequent water application, sufficient to wet the top $0.6 \mathrm{~m}$ of peanut field in light -textural soil, while furrow irrigation is frequently used on medium textural 
soils. Sprinkler irrigation systems with low irrigation frequencies increases yield and water use efficiency due to decreasing water losses during the irrigation season. Timing of irrigation should conform to soil water depletion requirements of the crop which are shown to vary considerably with evaporative demand, rooting depth and soil type as well as with stages of crop growth. Irrigation timing affects peanut pod yield mainly by influencing the duration of pod production (Plaut and Ben-Hur, 2005). Doorenbos and Kassam (1986) reported that the crop coefficient values for peanut crop were $0.45,0.75,1.05,0.8$ and 0.55 for initial, development, mid- season, lateseason and at harvest stage, respectively. Allen et al. (1998) mentioned that the crop coefficient values for peanut crop were $0.50,0.80,0.98,0.8$ and 0.55 for the same growth stages, respectively. Rao et al. (1985) stated that the greatest reduction in kernel yield of peanut occurred when water stress was imposed during the seed filling growth stage. Also, many researchers mentioned that water stress during the flowering and pegging stages produced the greatest reductions in pod yield followed by water stress at the early-and late - pod stages. Attia and Hammad (1999) stated that maximum peanut pod yield was $1378.7 \mathrm{~kg} /$ fed with newly reclaimed sandy soils under drip irrigation system. While, seasonal amount of applied irrigation water and seasonal water consumptive use were 2835 and $2261.7 \mathrm{~m}^{3} /$ fed., respectively. Mohsen, (2001) studied the effects of irrigation intervals, quantities of irrigation water and fertilization methods on peanut productions. Obtained results showed that, the effect of irrigation interval was highly significant on peanut yield, while the effects of irrigation quantities and fertilization methods were not significant. Abdrabbo (2009) stated that the average seasonal actual $\mathrm{K}_{\mathrm{C}}$ value of peanut $(0.78)$ is approximately close to the FAO- $56 \mathrm{~K}_{\mathrm{C}}(0.66)$ and FAO-33 $\mathrm{K}_{\mathrm{C}}(0.70)$ Values. Also, the irrigation amount of peanut averaged $587 \mathrm{~mm}$ and ranged from 545 to $640 \mathrm{~mm}$. Kamal et al. (2010) investigated that, the response of peanut crop to non-uniformity of irrigation application under sprinkler irrigation in sandy soil. They reported that the peanut yield was significantly affected by both irrigation amount and non- uniformity caused by sprinkler layouts and water overlapping. Genetic $\mathrm{K}_{\mathrm{C}}$ values for a number of crops grown under different climatic conditions were listed in FAO-33 and FAO-56, indicating only the climate, cropping season and yield, without considering the cultivar and site specifications under given climate conditions. Therefore estimating site and cultivar specific $K_{C}$ value under given climate conditions is essential for improving irrigation management. Also, calibration of local or regional of FAO- $K_{C}$ curve is strongly recommended for achieving the accuracy of irrigation scheduling and water allocation. The specific objectives of this research were as folloos: 
1- Identifying suitable irrigation scheduling strategy and agricultural practices for reducing crop water use and enhancing productivity and quality of peanut crop.

2- Assessment the impact of different irrigation regimes and mulching treatments on water consumptive use and water use efficiencies.

3- Developing and comparing site- and cultivar-specific peanut crop coefficients with the values listed in FAO- $33 \mathrm{~K}_{\mathrm{C}}(0.07)$ and FAO $\mathrm{K}_{\mathrm{C}}(0.66) 56$.

\section{MATERIALS AND METHODS}

\section{Experimental site:}

Field experiments were carried out during the summer season of 2013 at ElBustan Agricultural Research Station, Behera Governorate, Egypt. Peanut (Arachis hypogaea L.) variety Giza 5 was planted to study the effect of different sprinkler irrigation regimes and rice straw mulch treatments on yield, water consumptive use and, water use efficiency and to identify the peanut crop factor under site conditions. Soil samples were collected at $20 \mathrm{~cm}$ increments to a depth of $60 \mathrm{~cm}$ to determine some physical and chemical properties. Obtained results are presented in Table (1).

Table 1. Some physical and chemical properties of the experimental site.

\begin{tabular}{|c|c|c|c|c|c|c|c|c|c|c|}
\hline \multirow{2}{*}{$\begin{array}{l}\text { Soil } \\
\text { depth } \\
(\mathrm{cm})\end{array}$} & \multicolumn{3}{|c|}{$\begin{array}{c}\text { Mechanical analysis } \\
(\%)\end{array}$} & \multirow{2}{*}{$\begin{array}{l}\text { Texture } \\
\text { class }\end{array}$} & \multirow{2}{*}{$\begin{array}{l}\mathrm{FC} \\
(\%)\end{array}$} & \multirow{2}{*}{$\begin{array}{l}\text { WP } \\
(\%)\end{array}$} & \multirow{2}{*}{$\begin{array}{l}\text { ASM } \\
(\%)\end{array}$} & \multirow{2}{*}{$\begin{array}{l}\text { B.D } \\
\text { g. } / \mathrm{cm}^{3}\end{array}$} & \multirow{2}{*}{$\begin{array}{c}\mathrm{pH} \\
1 / 2.5\end{array}$} & \multirow{2}{*}{$\begin{array}{l}\mathrm{EC} \\
\mathrm{dS} / \mathrm{m}\end{array}$} \\
\hline & Sand & Silt & Clay & & & & & & & \\
\hline $0-20$ & 93.2 & 4.2 & 2.6 & Sandy & 10.6 & 6.1 & 4.5 & 1.52 & 8.25 & 1.27 \\
\hline $20-40$ & 93.1 & 4.1 & 2.8 & Sandy & 10.9 & 5.8 & 5.1 & 1.55 & 8.3 & 1.25 \\
\hline $40-60$ & 93.0 & 4.3 & 2.7 & Sandy & 10.8 & 5.2 & 5.6 & 1.58 & 8.3 & 1.26 \\
\hline
\end{tabular}

\section{Crop management:}

Peanut seeds Varity Giza 5 at a rate of $50 \mathrm{~kg} / \mathrm{fed}$. were sown on 23 May in rows $50 \mathrm{~m}$ length, $0.6 \mathrm{~m}$ width and about $0.2 \mathrm{~m}$ spacing between plants within rows. The experiments were terminated on 25 September 2013. All agricultural practices for peanut production as well as chemical fertilizer quantity were followed as recommended for peanut production at the experimental site. Water application of 25 $\mathrm{mm}$ was applied over the entire field area after planting to enhance germination and ensure uniform growth. Irrigation management strategies were initiated at the second irrigation. An additional light irrigation of about $20 \mathrm{~mm}$ was applied to the entire field shortly before uprooting to improve the soil turn over and to minimize pods loss. Plants were manually uprooted and trashed with a hand trash after air drying of about 3 days. Samples were taken to determine some productivity parameters, pods, straw yields, oil and protein percentage of seeds. 


\section{Irrigation system and Treatments:}

Sprinkler irrigation system was used in this experiment. It consisted of control head unit, which located at the source of water supply, centrifugal pump with flow rate of $60 \mathrm{~m}^{3} / \mathrm{h}$ at operating pressure of $400 \mathrm{kPa}$, sand media filter of 100 mesh followed by screen filter of 120 mesh, pressure gauges, pressure regulator, control valves fertilizer tank and flow meter. The control head unit was connected to the main line with110 mm in diameter PVC, sub-main line of $90 \mathrm{~mm}$ PVC and sprinkler line of $75 / 63 \mathrm{~mm}$ PVC. Sprinklers with spacing of $12 \times 12 \mathrm{~m}$ with two nozzles of 2 and $2.8 \mathrm{~mm}$ in diameter were used. The sprinkler discharge and operating pressure were 1.20 $\mathrm{m}^{3} / \mathrm{h}$ and $223 \mathrm{kPa}$. Steel risers of $26.7 \mathrm{~mm}$ in diameter were used .The riser length was $1.20 \mathrm{~m}$ in length ( $40 \mathrm{~cm}$ buried under ground and $80 \mathrm{~cm}$ above the soil surface). Irrigation water was obtained from El-Nasar open channel irrigation system in the experimental area and classified by $\mathrm{pH}$ value of 7.8 with average electrical conductivity of $1.12 \mathrm{dS} / \mathrm{m}$. Two irrigation treatments, $\left(I_{3}\right)$ and $\left(I_{5}\right)$ were imposed based on the soil water depletion to bring the soil water deficit to the field capacity at two irrigation intervals of 3 and 5 days, respectively. Mulching treatments were applied randomly to one half of the experimental area $(M)$, while the other half remained bare (non-mulched, $M_{0}$ ), the mulch was a flat rice straw mulch (inexpensive organic residue, locally available, insulate well and conserve moisture) approximately 3.5 to $4 \mathrm{~cm}$ thickness (about $500 \mathrm{~g} / \mathrm{m}^{2}$ ) which covered the entire soil surface. Mulching over $5 \mathrm{~cm}$ thickness was avoided to overcome mulching problems (Khalifa et al., 2011). Rice straw mulch was applied at about 3-leaf growth stage. The experimental design was a split plot with three replications. Two irrigation regimes and two mulching treatments were evaluated. Main plots were assigned to two irrigation treatments $\left(\mathrm{I}_{3}\right)$ and $\left(\mathrm{I}_{5}\right)$. The subplots were assigned to mulching treatments $\left(M, M_{0}\right)$, which were randomly distributed. The treatment of $I_{3} M_{0}$ represented the control treatment. The experimental area of about three fed. was divided into two plots, each was $70 \mathrm{~m}$ long and $90 \mathrm{~m}$ width. Each plot was divided into 6 subplots, each was $60 \mathrm{~m}$ long and $12 \mathrm{~m}$ in width $\left(720 \mathrm{~m}^{2}\right)$. A buffer zone of $10 \mathrm{~m}$ separated between treatments and $3 \mathrm{~m}$ separated between replicates to avoid interference.

\section{Soil water content and evapotranspiration measurements $\left(E T_{C}\right)$ :}

The soil water content was measured using the gravimetric soil samples. Measurements were regularly made at $0.20 \mathrm{~m}$ increments to a depth of $0.60 \mathrm{~m}$ before and after each irrigation event in the course of the season. Applied irrigation water was determined before each irrigation according to water consumed during irrigation intervals measured as the difference between soil moisture content at field capacity and the moisture content before next irrigation plus $15 \%$ as leaching requirement and 
considering the efficiency of the irrigation system. The depth of water to be applied to bring the soil water deficit to the field capacity and water consumptive use were calculated according to Hansen et al. (1979) as follow:

$$
\begin{gathered}
D_{\text {aiw }}=\sum_{\substack{i=1 \\
i=3}}^{i=3 C-\theta 1} \frac{F}{100} R_{i} \times \rho_{s i} \\
E T_{c}=\sum_{i=1}^{\theta 2-\theta 1} \frac{\theta 1}{100} R_{i} \times \rho_{s i}
\end{gathered}
$$

Where:

$\mathrm{D}_{\mathrm{aiw}}=$ depth of irrigation water to be applied, $\mathrm{mm}$

$\mathrm{ET}_{\mathrm{c}}$ = water consumptive use, $\mathrm{mm}$

$\mathrm{I}=$ number of soil layers,

FC: soil moisture content at field capacity, \%,

$\theta 1$ = soil moisture content before next irrigation, $\%$,

$\theta 2=$ soil moisture content after irrigation, $\%$

$R_{i}=$ is the soil layer thikness, $m m$ and

$\rho_{\mathrm{si}}=$ is the specific density of the soil layer

The depth of irrigation water applied in each irrigation event $\left(\mathrm{I}_{\mathrm{rd}}\right)$ was calculated as:

$$
\mathbf{I}_{\mathrm{rd}}=\frac{\mathrm{D}_{\mathrm{siw}}}{\tau \times(1-\mathrm{LR})}
$$

Where:

$$
\tau=\text { irrigation effeciency }(\%) \text { and }
$$

\section{$\mathrm{LR}=$ Leaching requirment.}

\section{Determination of crop coefficient $\mathbf{K}_{\mathbf{c}}$ :}

Crop coefficient $\left(\mathrm{K}_{\mathrm{c}}\right)$ is defined by the ratio of the crop evapotranspiration to the reference evapotranspiration as:

$$
\mathrm{Kc}=\frac{\mathrm{ET}_{\mathrm{c}}}{\mathrm{ET}_{\mathrm{o}}}
$$

Crop coefficient $\left(\mathrm{K}_{\mathrm{c}}\right)$ was calculated from the estimated $\mathrm{ET}_{\mathrm{C}}$ of the peanut crop under optimal growth conditions. The potential evapotranspiration $\left(E T_{0}\right)$ was calculated on a daily basis (mm/day) using CROPWAT model based on penmanMonteith's formula as mentioned by Allen et al. (1998). Necessary metrological data used for these calculations are provided by the Central Laboratory for Agricultural Climate (CALC) of Egypt. The values of $\mathrm{K}_{\mathrm{C}}$ were compared to the $\mathrm{K}_{\mathrm{C}}$ values listed in FAO- 33 and- 56. 


\section{Water use Efficiencies:}

Water use efficiency (WUE, $\mathrm{kg} / \mathrm{m}^{3}$ ) and irrigation water use efficiency (IWUE, $\mathrm{kg} / \mathrm{m}^{3}$ ) were calculated as follows:

$$
\begin{aligned}
\text { WUE } & =\frac{Y}{\mathrm{ET}_{\mathrm{C}}} \\
\text { IWUE } & =\frac{\mathrm{Y}}{\mathrm{AIW}}
\end{aligned}
$$

Where:

$\mathrm{Y}$ is the kernels yield ( $\mathrm{kg} / \mathrm{fed}.), \mathrm{ET}_{\mathrm{C}}$ and AIW are the seasonal crop evapotranspiration and the seasonal applied irrigation water ( $\mathrm{m}^{3} / \mathrm{fed}$.), respectively.

\section{Plant data recorded:}

At harvest, random plants samples on $1 \mathrm{~m}$ section of the seven central rows $\left(4.20 \mathrm{~m}^{2}\right)$ in each experimental plot were taken to determine:

a- Plant length $(\mathrm{cm})$.

b- Number of pod and pod's weight/ plant ( $\mathrm{g})$.

c- Weight of 100 kernels $(\mathrm{g})$, and total kernels yield (kg/fed.).

d- Pod and straw yield ( $\mathrm{kg} / \mathrm{fed}$.).

e- Seeds oil and protein percentage based on the procedure of (AOAC), 1975.

\section{Statistical analysis:}

Statistical analysis of the collected data were subjected to the statistical analysis of variance (ANOVA). The statistical Package (CoHort, 1986) was used for data analysis. The probability level for determination of significance was 0.05 .

\section{RESULTS AND DISCUSSION}

\section{A: plant length (PL), cm:}

The data concerning the plant length of peanut are presented in Table (2). The statistical analysis of the obtained data showed highly significant effect of both treatments on the plant length. PL increased by about $10 \%$ under $(\mathrm{M})$ treatment than $\left(\mathrm{M}_{\mathrm{O}}\right)$ treatment, meanwhile, $7.1 \%$ increase in $\mathrm{PL}$ was obtained when the plant was irrigated every 3 days $\left(I_{3}\right)$ compared to $I_{5}$ treatments. A significant interaction of the treatments on PL was recorded. The maximum $\mathrm{PL}$ of $65.00 \mathrm{~cm}$ was obtained with $\mathrm{I}_{3} \mathrm{M}$ treatment while, the $\mathrm{I}_{5} \mathrm{Mo}$ treatment has the minimum $\mathrm{PL}$ of $54.20 \mathrm{~cm}$. These results emphasis that adequate soil moisture content in course of growing season enhanced the development of plant length.

\section{B: Number of pod / plant (PN/p):}

Results of the average number of pod per plant (PN/p) are given in Table (2). Obtained results showed highly significant influence of treatments on PN. The average 
values of maximum $P N / p$ were 37.95 and 37.26 with $I_{3}$ and $M$ treatments, respectively. Highly significant interaction effect of treatments on PN was noticed. $\mathrm{I}_{3} \mathrm{M}$ treatment had the maximum $\mathrm{PN} / \mathrm{p}$ of 39.45 followed by the control treatment $\left(\mathrm{I}_{3} \mathrm{M}_{\mathrm{O}}\right)$ and $I_{5} M$ treatments. $I_{5} M_{0}$ treatment had the minimum $P N / p$ value of 30.10 , about $17.33 \%$ less than the control treatment. These results declared that the effect of irrigation interval on $\mathrm{PN} / \mathrm{p}$ was more pronounced than the effect of mulching treatments. Irrigation every three days offer the best medium for plant growth as compared to irrigation every five days. These results agree with Mohsen, (2001).

\section{C: Pod weight per plant (Pw/p), g:}

Pod weight per plant $(\mathrm{Pw} / \mathrm{P})$ was investigated, and the results were presented in Table (2).The results showed highly significant effect of treatments on Pw/p. Applying irrigation every 5 days resulted in reducing the Pw/p by about $10.9 \%$. On the other hand, adding a thin layer of rice straw mulch to the soil surface led to an increase in the Pw/p about $13.77 \%$. The interaction effect of different irrigation regimes and mulching treatments on the $\mathrm{Pw} / \mathrm{p}$ was not noticed. $\mathrm{I}_{3} \mathrm{M}$ treatment had the maximum $\mathrm{PW} / \mathrm{p}$ of $53.20 \mathrm{~g}$ followed by $\mathrm{I}_{5} \mathrm{M}, \mathrm{I}_{3} \mathrm{M}_{0}$ and $\mathrm{I}_{5} \mathrm{M}_{0}$, respectively.

\section{D: Bio-mass yield ( $\mathrm{Kg} / \mathrm{fed}$.$) :$}

Some growth and productivity parameters of peanut were illustrated in Table (2) which, reflect highly significant effect of $M$ treatments on Bio- mass yield. Applying rice straw mulch lead to an increase in the Bio- mass yield about $28.90 \%$ as compared to $M_{0}$ treatments. On the other hand, irrigation every 5 days $\left(I_{5}\right)$, lead to a decrease in the bio- mass yield by about $12.3 \%$. A significant interaction effect of irrigation and mulching treatments on Bio-mass yield was observed, $\mathrm{I}_{3} \mathrm{M}$ and $\mathrm{I}_{5} \mathrm{M}$ treatments had the highest Bio-mass yield of 4012.05 and $3577.0 \mathrm{Kg} / \mathrm{fed}$, respectively. While, minimum Bio-mass yield $(2704.0 \mathrm{~kg} / \mathrm{fed})$ was obtained with $\mathrm{I}_{5}$ Mo treatment. These results confirmed that application of rice straw mulch, and irrigation every 3 days offered the adequate soil moisture content in course of the growing season and consequently enhanced the vegetative growth of peanut plant. These results agreed with Attia and Hammad, 1999 and Mohsen, 2001. 
Table 2. Some growth and productivity parameters of peanut as affected by different irrigation regimes and mulching treatments.

\begin{tabular}{|c|c|c|c|c|c|c|}
\hline & & \multicolumn{5}{|c|}{ Growth and productivity parameters of peanut } \\
\hline \multicolumn{2}{|c|}{ Treatments } & $\begin{array}{l}\text { Plant length } \\
\qquad(\mathrm{cm})\end{array}$ & $\begin{array}{c}\text { No. of } \\
\text { pod/plant }\end{array}$ & $\begin{array}{l}\text { Pod weight/plant } \\
\text { (g) }\end{array}$ & $\begin{array}{l}\text { T. Bio-mass } \\
\text { (kg/fed.) }\end{array}$ & $\begin{array}{c}100 \text { kernel } \\
\text { weight } \\
\text { (g) }\end{array}$ \\
\hline \multicolumn{2}{|c|}{$\mathrm{I}_{3}$} & $61.90 a$ & $37.95 a$ & $49.90 \mathrm{a}$ & $3634.55 a$ & $62.70 a$ \\
\hline \multicolumn{2}{|c|}{$\mathrm{I}_{5}$} & $57.80 \mathrm{~b}$ & $32.56 \mathrm{~b}$ & $45.00 \mathrm{~b}$ & $3188.01 \mathrm{~b}$ & $60.60 \mathrm{~b}$ \\
\hline \multicolumn{2}{|c|}{ Significance L. } & $* *$ & $* * *$ & $* *$ & $*$ & $*$ \\
\hline \multicolumn{2}{|c|}{ M } & $62.70 a$ & $37.26 a$ & $50.40 a$ & $3842.04 a$ & $67.00 \mathrm{a}$ \\
\hline \multicolumn{2}{|c|}{$M_{0}$} & $57.00 \mathrm{~b}$ & $33.25 b$ & $44.30 \mathrm{~b}$ & $2980.53 b$ & $56.50 \mathrm{~b}$ \\
\hline \multicolumn{2}{|c|}{ Significance L. } & $* * *$ & $* * *$ & $* * *$ & $* * *$ & $* * *$ \\
\hline \multirow[b]{2}{*}{$\mathrm{I}_{3}$} & M & \multirow[t]{2}{*}{65.00} & \multirow{2}{*}{$\begin{array}{l}39.45 \\
36.41 \\
\end{array}$} & \multirow{2}{*}{$\begin{array}{l}53.20 \\
46.50 \\
\end{array}$} & \multirow{2}{*}{$\begin{array}{l}4012.05 \\
3223.73 \\
\end{array}$} & \multirow{2}{*}{$\begin{array}{l}67.10 \\
58.40 \\
\end{array}$} \\
\hline & $M_{0}$ & & & & & \\
\hline \multirow[b]{2}{*}{$\mathrm{I}_{5}$} & M & \multirow{2}{*}{$\begin{array}{l}61.70 \\
54.20 \\
\end{array}$} & \multirow{2}{*}{$\begin{array}{l}35.10 \\
30.10 \\
\end{array}$} & \multirow{2}{*}{$\begin{array}{l}47.60 \\
42.20 \\
\end{array}$} & \multirow{2}{*}{$\begin{array}{l}3572.02 \\
2704.00 \\
\end{array}$} & \multirow{2}{*}{$\begin{array}{l}66.80 \\
54.60 \\
\end{array}$} \\
\hline & $M_{0}$ & & & & & \\
\hline \multicolumn{2}{|c|}{ Significance L. } & $*$ & $* * *$ & ns & $*$ & $* * *$ \\
\hline
\end{tabular}

Means within each column followed by the same letter/s are insignificant at 0.05 level of probability, $*$ : significance at the 0.05 probability level, $* *$ : significance at the 0.01 probability level and $* * *$ : significance at the 0.001 probability level.

\section{E: Average weight of $\mathbf{1 0 0}$ kernels (g):}

Results of the average weight of 100 kernels are given in Table (2). Data obtained pointed out a highly significant effect of treatments on the kernels weight. Also, results demonstrated highly effect of mulching treatment on the kernels weight than the irrigation treatments. An increase of $18.60 \%$ in 100 kernels weight occurred with $M$ treatment as compared with $M_{0}$ treatments. Concerning the irrigation intervals, $\mathrm{I}_{5}$ treatments led to a decrease in the 100 kernels weight by about $3.35 \%$ as compared to $I_{3}$ treatments. A significant interaction among the treatments was noticed. $\mathrm{I}_{3} \mathrm{M}$ treatment resulted in the highest average weight of 100 kernels of 67.0 $\mathrm{g}$, while the lowest average weights of 100 kernels of 58.40 and $54.60 \mathrm{~g}$ were obtained with $I_{3} M_{0}$ and $I_{5} M_{0}$ treatments, respectively. These results indicated that $I_{3}$ and $M$ treatments offer adequate soil moisture content that is sufficient to prevent water stress during flowering and pod filling growth stages and enhancing the availability of nutrients located in deeper layers and consequently enhancing the pods and kernels growth. These results agree with Plaut and Ben-Hur (2005). 


\section{F-Total pods yield ( $\mathrm{kg} /$ fed.):}

Total pods yield under different treatments are presented in Table (3). The statistical analysis showed that the pods yield was significantly affected by treatments. Applying water irrigation every 5 days $\left(I_{5}\right)$ led to reduce the total pods yield by about $13.27 \%$, while applying rice straw mulch enhanced the total pods yield by about $14.57 \%$. A significant interaction of the treatments on the total pods yield was noticed. $\mathrm{I}_{3} \mathrm{M}$ treatment resulted in the highest value of total pods yield of 1658.80 $\mathrm{kg} / \mathrm{fed}$, while $\mathrm{I}_{5} \mathrm{M}_{0}$ treatment resulted in the lowest value of total pods yield of $1236.91 \mathrm{~kg} / \mathrm{fed}$. There were a slight difference in the total pods yield between the control $\left(I_{3} M_{0}\right)$ and $I_{5} M$ treatments. The increase in pods yield under $I_{3}$ and $M$ treatments compared to other treatments can be explained by the significant increase in pod numbers and weight per plant under the same treatments.

\section{G-Total kernels yield ( $\mathrm{kg} / \mathrm{fed}$.):}

Results of the total kernels yield had the same trend of the total pods yield. These results reflect highly significant effect of the $\mathrm{M}$ and $\mathrm{I}_{3}$ treatments on the kernels yield as shown in Table (3). Also, highly significant interaction among the treatments was noted. The highest values of kernels yield of $1176.00,1036.50$ and $1108.25 \mathrm{~kg} / \mathrm{fed}$. were obtained under $I_{3} M, I_{3} M o$ and $I_{5} M$ treatments, respectively. These results reflected an important factor that if the irrigation water is not available every three days, it can be irrigated every five days simultaneously with applying rice straw mulch with an increase of kernels yield by about $6.96 \%$ as compared to the control treatment. On the other hand, $\mathrm{I}_{5} \mathrm{M}_{0}$ treatment had the minimum kernels yield of $802.50 \mathrm{Kg} / \mathrm{fed}$ with a reduction of $22.60 \%$ as compared to the control treatments.

\section{H-Shelling (\%):}

The shelling percentage was significantly affected by mulching treatments, meanwhile no significant effect of irrigation treatments was noted as presented in Table (3). Also, there was non- significant interaction effect among the treatments on the shelling percentage. The highest values of shelling percentage of 70.90 and $70.0 \%$ were obtained with $\mathrm{I}_{3} \mathrm{M}$ and $\mathrm{I}_{5} \mathrm{M}$ treatments, respectively. These results are in harmony with those of number of pod per plant, pod weight per plant and 100 kernels weight.

\section{I-Protein and oil percentage (\%):}

The highest values of protein and oil percentages were obtained under $\mathrm{I}_{3}$ and $\mathrm{M}$ treatments as shown in Table (3). Applying water irrigation every five days resulted in reducing the protein and oil percentages, while application of rice straw mulch enhanced these percentages. Non-significant interaction effect of the treatments on the protein and oil percentage was noticed. $\mathrm{I}_{3} \mathrm{M}$ treatment had the highest protein and 
oil percentage of 21.61 and $50.83 \%$, respectively, while $\mathrm{I}_{5} \mathrm{M}_{0}$ treatment had the lowest protein and oil content of 19.62 and $48.57 \%$, respectively.

Table 3.Yield and some quality parameters of peanut as affected by different irrigation regimes and mulching treatments.

\begin{tabular}{|c|c|c|c|c|c|c|}
\hline \multirow{2}{*}{\multicolumn{2}{|c|}{ Treatments }} & \multicolumn{5}{|c|}{ Growth and productivity parameters of peanut } \\
\hline & & $\begin{array}{c}\text { T. pod yield } \\
\text { (kg/fed.) }\end{array}$ & $\begin{array}{c}\text { T.kernel } \\
\text { yield } \\
\text { (kg/fed.) }\end{array}$ & $\begin{array}{c}\text { Shelling } \\
\text { (\%) }\end{array}$ & $\begin{array}{c}\text { Protein } \\
\qquad \%)\end{array}$ & $\begin{array}{l}\text { Oil } \\
(\%)\end{array}$ \\
\hline & $\mathrm{I}_{3}$ & $1625.40 a$ & $1105.25 a$ & $66.6 a$ & $21.40 a$ & $50.30 a$ \\
\hline & $I_{5}$ & $1409.66 \mathrm{~b}$ & $954.00 \mathrm{~b}$ & $66.40 \mathrm{a}$ & $20.72 b$ & $48.93 b$ \\
\hline \multicolumn{2}{|c|}{ Significance L. } & $* * *$ & $* *$ & ns & $* *$ & $* *$ \\
\hline \multicolumn{2}{|c|}{$M$} & $1620.60 a$ & $1142.12 \mathrm{a}$ & $66.75 a$ & $21.53 a$ & $50.07 a$ \\
\hline \multicolumn{2}{|c|}{$M_{0}$} & $1414.46 \mathrm{~b}$ & $918.00 \mathrm{~b}$ & $64.55 b$ & $20.60 \mathrm{~b}$ & $49.17 \mathrm{~b}$ \\
\hline \multicolumn{2}{|c|}{ Significance L. } & $* * *$ & $* * *$ & $* *$ & $* * *$ & $* *$ \\
\hline \multirow{2}{*}{$\mathrm{I}_{3}$} & M & 1658.80 & 1176.00 & 70.90 & 21.61 & 50.83 \\
\hline & $M_{0}$ & 1592.00 & 1036.50 & 65.10 & 20.70 & 49.77 \\
\hline \multirow{2}{*}{$\mathrm{I}_{5}$} & $M$ & 1582.41 & 1108.26 & 70.00 & 21.10 & 49.39 \\
\hline & $M_{0}$ & 1236.91 & 802.50 & 64.88 & 19.62 & 48.57 \\
\hline \multicolumn{2}{|c|}{ Significance L. } & $* * *$ & $* * *$ & ns & ns & ns \\
\hline
\end{tabular}

Means within each column followed by the same letter/s are insignificant at 0.05 level of probability,*: significance at the 0.05 probability level, $* *$ : significance at the 0.01 probability level and $* * *$ : significance at the 0.001 probability level.

\section{Potential evapotranspiration (ETo):}

Potential evapotranspiration values were calculated based on the agro metrological data collected for the studing area, using the CROPWT model. Table (4) shows values of $\mathrm{ET}_{\mathrm{O}}$ through the growth stages of peanut. $\mathrm{ET}_{\mathrm{O}}$ values fluctuated due to the change in weather conditions as shown in Fig, (1).The average values of daily $\mathrm{ET}_{\mathrm{O}}$ during the peanut growing season was $6.02 \mathrm{~mm} /$ day. $\mathrm{ET}_{\mathrm{O}}$ values increased to 7.15 $\mathrm{mm} /$ day in July when most of weather elements increased. The seasonal $\mathrm{ET}_{O}$ value during the growing season of peanut was $752.25 \mathrm{~mm}$.

\section{Evapotranspiration of peanut $\left(\mathrm{ET}_{\mathrm{C}}\right)$ :}

$E T_{C}$ values were estimated in the course of the growing season for different treatments and illustrated in Table (5). The seasonal $\mathrm{ET}_{\mathrm{C}}$ values varied due to the change in the environmental conditions, plant growth development and treatments. It is clear that $\mathrm{ET}_{\mathrm{C}}$ values increased as the plant age progressed till the mid- season growth stage, then the rate was decreased till the end of the growing season. Also, it 
was noticed that $\mathrm{ET}_{\mathrm{C}}$ values increased with higher frequent irrigations (three days) due to increasing the soil water depletion, meanwhile, $\mathrm{ET}_{\mathrm{C}}$ values decreased with $\mathrm{M}$ treatments as compared to $M_{0}$ treatments. It could be due to the reduction of incoming solar energy, resulted in less evaporated water from the mulched plots compared to the non-mulched plots for all irrigation treatments. Applying mulch reduced the soil moisture depletion by about $81-107 \mathrm{~mm}$. Maximum $\mathrm{ET}_{\mathrm{C}}$ value (2415 $\mathrm{m}^{3} / \mathrm{fed}$ ) was occurred with $\mathrm{I}_{3} \mathrm{M}_{\mathrm{O}}$, while, minimum $\mathrm{ET}_{\mathrm{C}}$ value $\left(1860.6 \mathrm{~m}^{3} / \mathrm{fed}\right)$ was occurred with $\mathrm{I}_{5} \mathrm{M}$. Reduction of $\mathrm{ET}_{\mathrm{C}}$ due to mulching was reported for many other crops (Gouranga and Ashwani, 2007).

Table 4. $\mathrm{ET}_{\mathrm{O}}$ values through the different growth stages of peanut.

\begin{tabular}{|c|c|c|c|c|c|}
\hline Growth stages & Initial & Development & Mid-season & Late- season & Total \\
\hline Duration (days) & 25 & 45 & 35 & 20 & 125 \\
\hline Avg. mm/day & 5.66 & 6.49 & 6.1 & 5.26 & 6.02 \\
\hline $\mathrm{mm} /$ stage & 141.50 & 292.05 & 213.5 & 105.2 & 752.25 \\
\hline
\end{tabular}

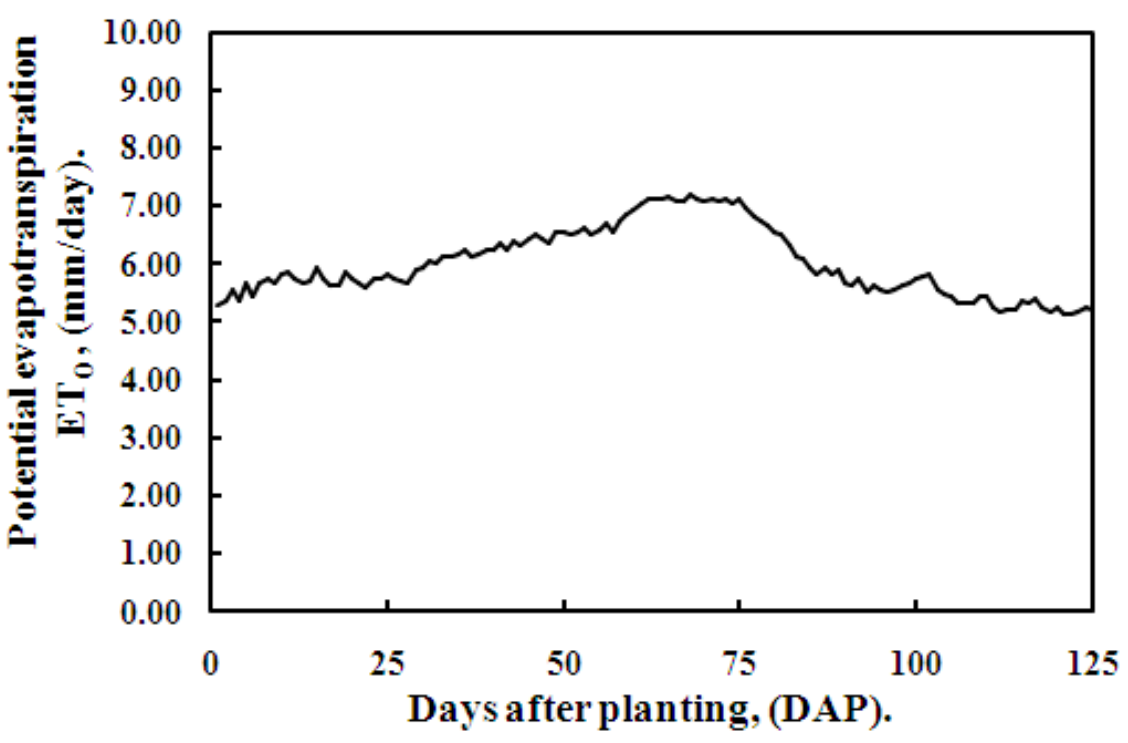

Fig. 1. Potential evapotranspiration in the course of the growing season of peanut during the summer season of 2013.

\section{Applied Irrigation water to peanut (AIW):}

The total amount of water applied, i.e., the sum of the preliminary application, the brief pre-harvest irrigation, and the sprinkler irrigation events, are presented in Table (5). The lower the irrigation frequency (five days), the smaller the total amount of water applied, because higher evaporation rates are expected with more frequent irrigations (three days), and probably contributed to higher soil deficits. The control treatment $\left(\mathrm{I}_{3} \mathrm{M}_{\mathrm{O}}\right)$ had the highest AIW value of $2952.6 \mathrm{~m}^{3} / \mathrm{fed}$, while, $\mathrm{I}_{5} \mathrm{M}$ treatment 
had the lowest AIW value of $2314.2 \mathrm{~m}^{3} / \mathrm{fed}$. Applying rice straw mulch saved about 14.37 and $21.62 \%$ irrigation water with $\mathrm{I}_{3} \mathrm{M}$ and $\mathrm{I}_{5} \mathrm{M}$ treatments, respectively as compared to the control treatment.

Table 5. $\mathrm{ET}_{\mathrm{C}}$ values and AIW through the different growth stages of peanut.

\begin{tabular}{|c|c|c|c|c|c|c|c|c|}
\hline & & & & & Mid- & Late- & & tal \\
\hline Durat & $(d$ & & 25 & 45 & 35 & 20 & $(\mathrm{~mm})$ & ( $\mathrm{m}^{3} /$ fed. $)$ \\
\hline & & M & 52 & 192 & 162 & 62 & 468 & 1965.6 \\
\hline $\mathrm{ET}_{\mathrm{c}}$ & & $M_{0}$ & 85 & 221 & 187 & 82 & 575 & 2415 \\
\hline$(\mathrm{mm})$ & & M & 58 & 173 & 155 & 57 & 443 & 1860.6 \\
\hline & & $M_{0}$ & 75 & 216 & 165 & 68 & 524 & 2200.8 \\
\hline & & M & 82 & 218 & 172 & 85 & 602 & 2528.4 \\
\hline AIW* & & $M_{0}$ & 128 & 235 & 201 & 94 & 703 & 2952.6 \\
\hline$(\mathrm{mm})$ & & $M$ & 72 & 195 & 163 & 76 & 551 & 2314.2 \\
\hline & & $M_{0}$ & 123 & 226 & 193 & 86 & 673 & 2826.6 \\
\hline
\end{tabular}

*The total amount of water applied included the sum of the preliminary application, the brief preharvest irrigation, and the sprinkler irrigation events.

\section{Developing crop coefficient $\left(K_{C}\right)$ :}

Site- and cultivar- specific $\mathrm{K}_{\mathrm{c}}$ of peanut (Cv. Giza 5 ) cultivated in sandy soil under El-Bustan region conditions during each growth stage, was developed .Fig (2) and Table (6) illustrate the average calculated crop coefficient of peanut under different treatments. $K_{C}$ values differ from the average values of FAO -33 and FAO 56 , as shown in Fig (2) during the initial and mid-season stages. These differences may be attributed to the specific cultivar and the changes in the environmental conditions. On comparison among $\mathrm{K}_{\mathrm{C}}$ values developed by the control treatment $\left(\mathrm{I}_{3} \mathrm{M}_{\mathrm{O}}\right)$ and FAO-33and FAO - 56, the maximum value of actual $\mathrm{K}_{\mathrm{C}}$ of 0.88 occurred at the mid- season is less than the values listed in FAO -33 and FAO - 56 by about $16.2 \%$ and $10.2 \%$, respectively. During the initial growth stage the actual $\mathrm{K}_{\mathrm{C}}$ value was $33.3 \%$ and $20.0 \%$ higher than FAO-33 and -65 , respectively. Nevertheless, during the crop development and late- season growth stages actual $\mathrm{K}_{\mathrm{C}}$ values were approximately close to the FAO -33 and FAO $-65 \mathrm{~K}_{\mathrm{C}}$ values. The average seasonal actual $\mathrm{K}_{\mathrm{C}}$ value of 0.73 was identical and close to the FAO- $56 \mathrm{~K}_{\mathrm{C}}$ value and $1.40 \%$ higher than $\mathrm{FAO}-33 \mathrm{~K}_{\mathrm{C}}$ value. These results reflected the difficulty in extrapolating crop coefficients to other environments, and also applying crop coefficient in individual year with differing crop 
development patterns. Hence, this attempt is needed to experimentally verify the estimates locally for optimum irrigation planning and management.

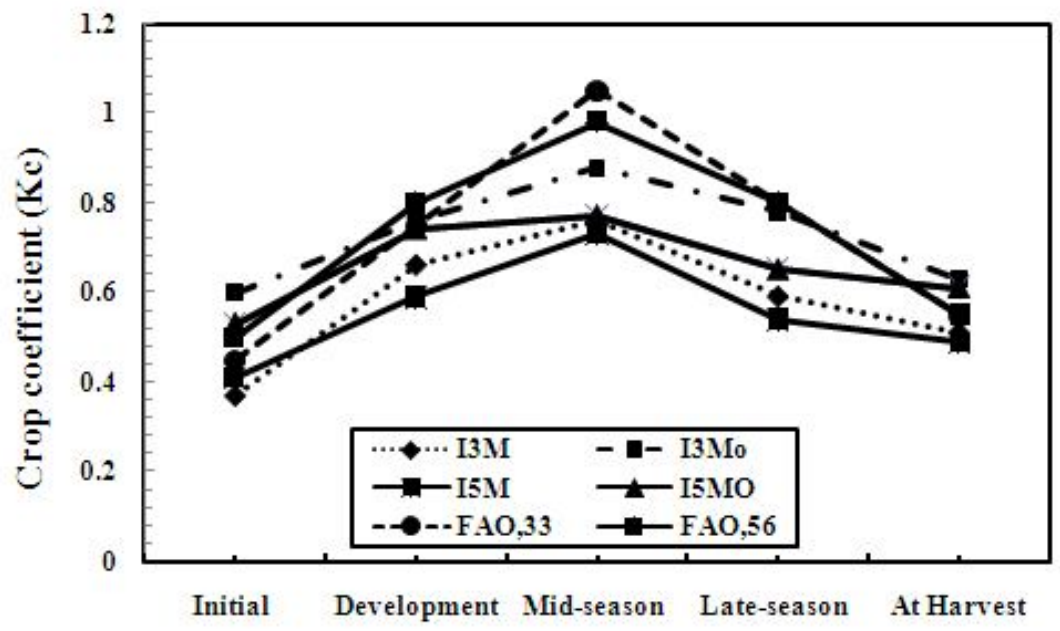

Growth stags

Fig. 2. Actual crop coefficient of peanut $\left(K_{C}\right)$ under different treatments compared to the values of $\mathrm{K}_{\mathrm{C}}$ listed in FAO-33 and- FAO 56.

Table 6. Comparison between calculated and reported FAO peanut crop coefficients $\left(K_{C}\right)$ for different growth stages for the control treatment $\left(I_{3} M_{0}\right)$.

\begin{tabular}{|c|c|c|c|c|c|}
\hline \multirow{2}{*}{ Growth stage } & \multirow{2}{*}{$\begin{array}{c}\mathrm{ET}_{\mathrm{O}} \\
\mathrm{mm} / \mathrm{day}\end{array}$} & \multirow{2}{*}{$\begin{array}{c}\mathrm{ET}_{\mathrm{c}} \\
\mathrm{mm} / \text { day }\end{array}$} & \multirow{2}{*}{ calculated $\mathrm{K}_{\mathrm{C}}$} & \multicolumn{2}{|c|}{ Reported FAO K ${ }_{C}$} \\
\hline & & & & $\mathrm{FAO}, 33$ & $\mathrm{FAO}, 56$ \\
\hline initial & 5.66 & 3.40 & 0.60 & 0.45 & 0.50 \\
\hline Development & 6.49 & 4.90 & 0.76 & 0.75 & 0.80 \\
\hline Mid-season & 6.1 & 5. 34 & 0.88 & 1.05 & 0.98 \\
\hline Late- season & 5.26 & 4.10 & 0.78 & 0.80 & 0.80 \\
\hline At harvest & 5.20 & 3.25 & 0.63 & 0.55 & 0.55 \\
\hline Seasonal Average & & & 0.73 & 0.72 & 0.73 \\
\hline
\end{tabular}

Water Use Efficiency (WUE) and Irrigation Water Use Efficiency (IWUE), $\mathbf{k g} / \mathbf{m}^{3}$ :

As shown in Fig (3), WUE and IWUE values varied considerably among the treatments. Applying rice straw mulch increased both of WUE and IWUE. Mulch produced a more favorable soil water regime compared with the bare soil treatments that significantly increased kernels yield and decreased both of $\mathrm{ET}_{\mathrm{C}}$ and AIW and consequently increased water use efficiency. $\mathrm{I}_{3} \mathrm{M}$ and $\mathrm{I}_{5} \mathrm{M}$ treatments resulted in the highest values of WUE and IWUE $(0.6,0.6)$ and $(0.47,0.48) \mathrm{kg} / \mathrm{m}^{3}$ respectively. Meanwhile, $I_{5} M_{0}$ treatment had the lowest values of WUI and IWUE, which were 0.36 and $0.28 \mathrm{~kg} / \mathrm{m}^{3}$, respectively. This might be attributed to the increased amount of water applied in $\mathrm{I}_{5} \mathrm{M}_{0}$ treatment resulting a higher crop water use without a corresponding increase in yield. These results confirmed that better management of 
available soil moisture content during the growing season, as well as accurate estimation of $\mathrm{ET}_{\mathrm{C}}$ and $\mathrm{K}_{\mathrm{C}}$ can be effective ways for better irrigation management, maximizing yield and consequently optimizing the economic return.

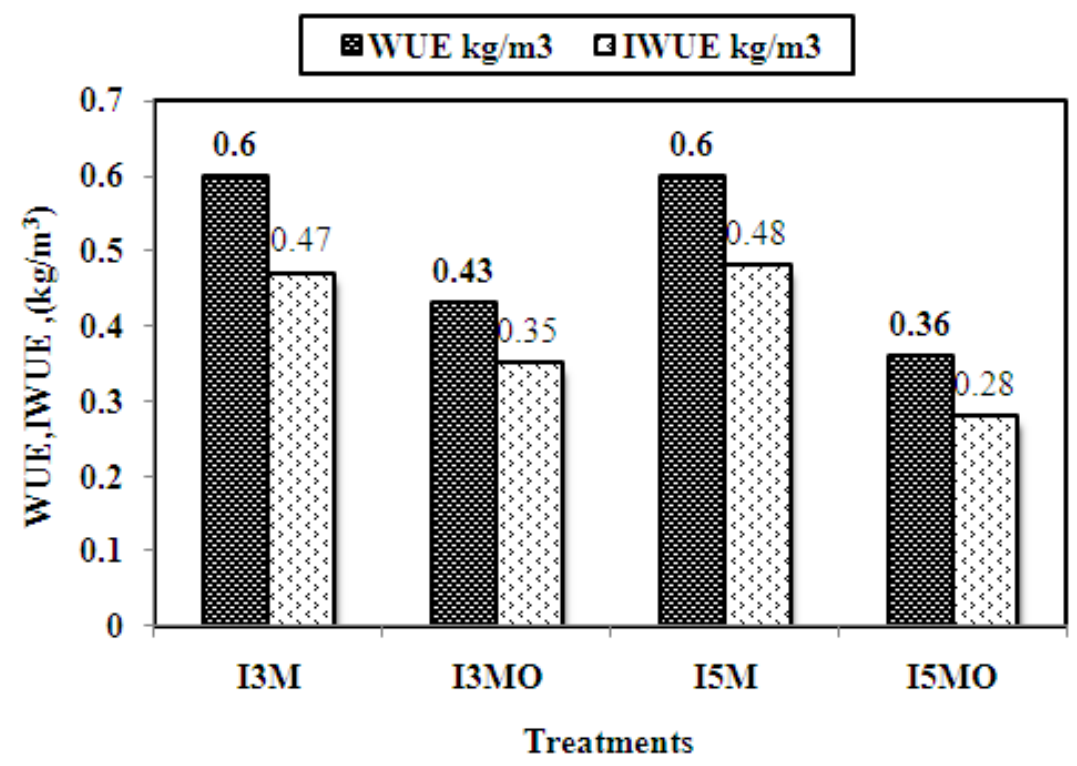

Fig. 3. Water use efficiency (WUE) and irrigation water use efficiency (IWUE), $\mathrm{kg} / \mathrm{m}^{3}$ as affected by irrigation and mulching treatments.

\section{CONCLUSION}

It could be concluded that better crop growth higher yield and quality were observed in the mulched plots as compared to non-mulched plots under the same irrigation treatments. Also, irrigation every three days was more pronounced than the effect of irrigation every five days. Maximum pods yield and total kernels yield were $1658.80 \mathrm{~kg} / \mathrm{fed}$ and $1176.00 \mathrm{~kg} / \mathrm{fed}$, respectively obtained with $\mathrm{I}_{3} \mathrm{M}$ treatment. An increase in the tested quality parameters such as shelling percent, protein and oil percentages, of $8.9,4.40$ and $2.13 \%$ was obtained with $\mathrm{I}_{3} \mathrm{M}$ treatment as compared to the control treatment $\left(\mathrm{I}_{3} \mathrm{M}_{\mathrm{O}}\right)$. Applying rice straw mulch conserved irrigation water by about 14.37 and $21.62 \%$ with $I_{3}$ and $I_{5}$ treatments, respectively. Maximum values of WUE were 0.6 and $0.6 \mathrm{~kg} / \mathrm{m}^{3}$ for $I_{3} M$ and $I_{5} M$, respectively. Meanwhile, minimum values of IWUE were 0.48 and $0.47 \mathrm{~kg} / \mathrm{m}^{3}$ for $I_{5} M$ and $I_{3} M$, respectively. The maximum crop coefficient $\left(K_{C}\right)$ value of 0.88 occurred during July, however the average $\mathrm{K}_{\mathrm{C}}$ values of peanut at El-Bustan area was 0.73 , which was close to the FAO listed values. These results revealed that precise management of the available soil moisture content in the course of the growing season, and accurate estimation of $\mathrm{ET}_{\mathrm{C}}$ as well as, developing site- and cultivar-specific $\mathrm{K}_{\mathrm{C}}$ value can be effective ways for appropriate irrigation scheduling and water allocation, saving water, maximizing yield and consequently optimizing the economic return. 


\section{REFERENCES}

1. Abdrabbo A. Abou-Kheira, 2009. Macromanagement of deficit -irrigated peanut with sprinkler irrigation. Agricultural Water Management $96,2009: 1409-1420$.

2. Allen, R. G. Pereira,L.S. rase, D. and Smith, M.1998. Crop evapotranspiration guide lines for computing crop water requirements. FAO irrigation and drainage paper, 56 Rome.

3. AOAC, Association of Official Agricultural Chemists. 1975. Official methods of analysis of association of official agriculture chemists. $12^{\text {th }}$ Ed. AOAC. Wash., USA.

4. Attia, M. M. and K. M. Hammad. 1999. Drip irrigation scheduling of peanut in sandy soil. Mansoura Univ. J. Ag. Sci. 24(11):7059-7069.

5. CoHort, Software. 1986. Costat 6.0 P.O. Box 1149, Berkeley, C A 94701, USA.

6. Doorenbos, J. and A. H. Kassam. 1986. Yield response to water. Irrigation and Drainage Paper No.33, FAO. Rome, Italy.

7. Ghosh, P. K., Devi Dayal, K. K.,bandyopadhyyay and M., Mohanty. 2006. Evaluation of straw and polythene mulch for enhancing productivity of irrigated summer groundnut. Field Crop Research, 99:76-86.

8. Gouranga, K. and K., Ashwani. 2007. Effect of irrigation and straw mulch on water use and tuber yield of potato in eastern India. Agricultural water management, 94(2007):109-116.

9. Hansen, V.E., O.W. Israelsen and G. E. Stringham. 1979. Irigation Principles $4^{\text {th }}$ Ed. John Wiley and Sos, New York, USA.

10. Hartz, T. K., 1993. Drip irrigation scheduling for fresh -market tomato production. Hortscience 28, 35-37.

11. Kamal, H. A., A. H. Gomaa and E. A. Farag. 2010. Peanut crop response to non-uniformity of irrigation application under sprinkler system performance. The $17^{\text {th }}$.Annual Conference of the Misr Society of Ag. 27(4):1193-1211.

12. Khalifa, E. M. and M. K. El-nemr. 2011. Econmical operation of drip irrigation system with rice straw mulching. Misr j.Ag. Eng., 28(3):650-661.

13. Mohsen, A. El-Adl, 2001.Sprinkler irrigation and fertigation effects on peanut production. Misr. J. Ag. Eng., 18(1):75-88.

14. Plaut, Z. and M. Ben-Hur. 2005. Irrigation management of peanut with moving sprinkler system, runoff, and water use efficiency. Argon. J. 97:1202-1208.

15. Rao.N., R.C. Sander Singh, M. V. K. Sivakumar, K. L. Srivastava and J. H. willams. 1985. Effect of water deficit at different growth phases of peanut 1Yield response. Agron. J. 77:549-553.

16. Raskar, B.S. and P.G. Bhoi. 2003. Response of summer ground nut in irrigation regimes and evaporation suppressants. Indian J. Agric. Sci., 73(2):82-85.

17. Reddy, T. Y., V. R., Reddy and V. Anhumazhi. 2003. Physiological responses of groundnut to drought stress and its amelioration. Plant growth regul. 41:75-88. 


\title{
تأثير ادارة الري بالرش والتفطية بالقش علي الإتتاجية و الإستهلاك المائي ومعامل المحصول للفول السوداني في الأراضي الرمليه
}

\author{
عب الحليم محمد زيتون ، آمون القص جرجس و خليل عبل الحليم علام \\ معهد بحوث الهندسة الزراعية - مركز البحوث الزراعية - الدقى - الجيزة.
}

يهدف هذا البحث الي دراسة. تأثثرادارة الري بالرش والتغطية بالقش علي الإنتاجية

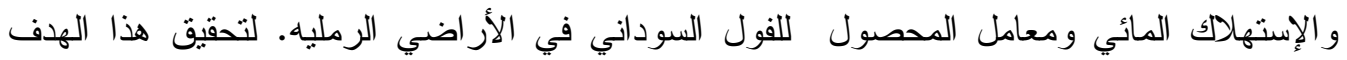

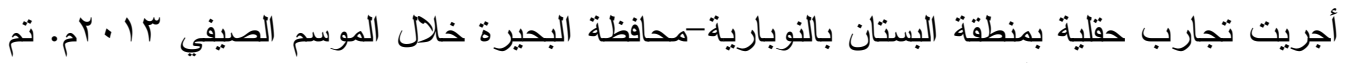

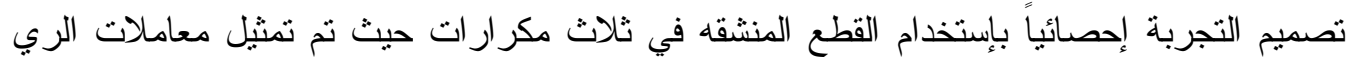

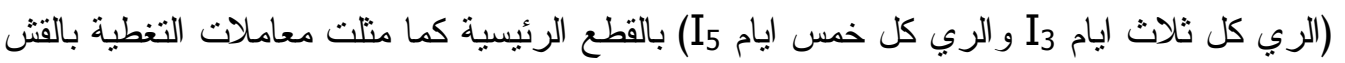

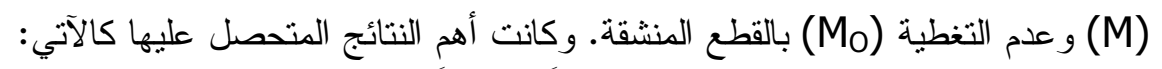

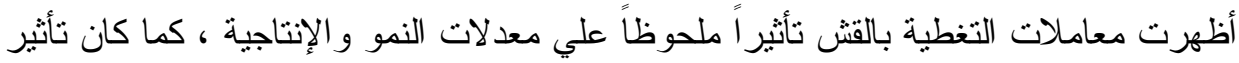

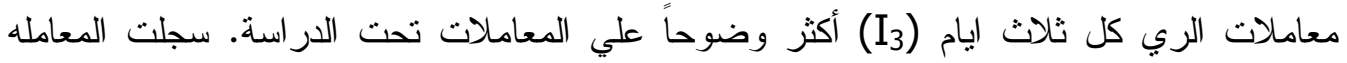

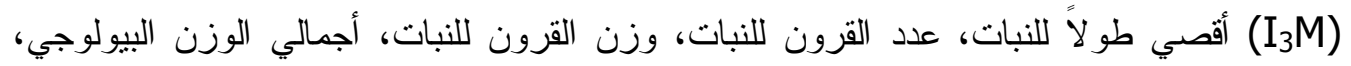

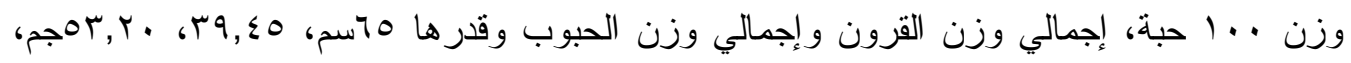

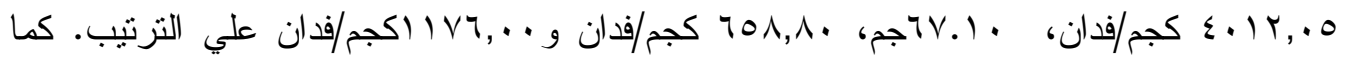

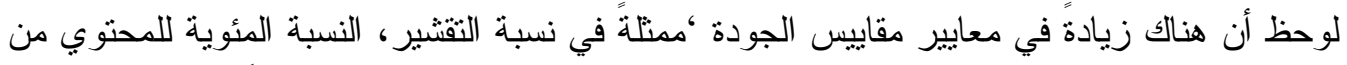

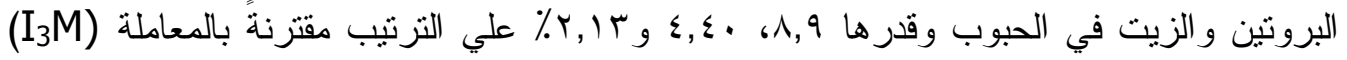

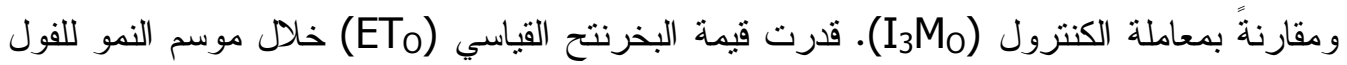

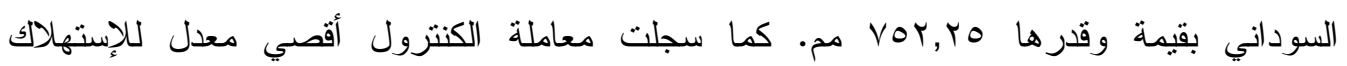

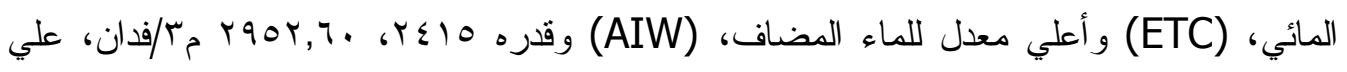

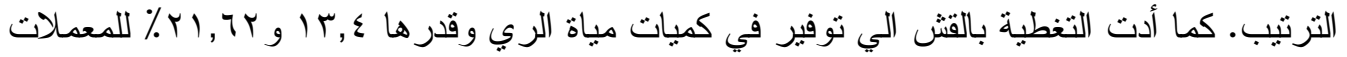

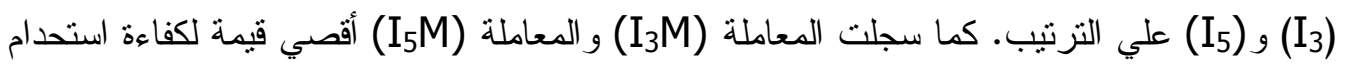

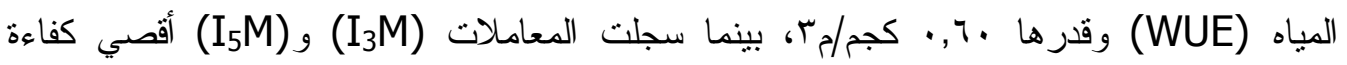

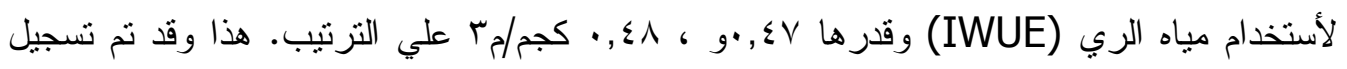

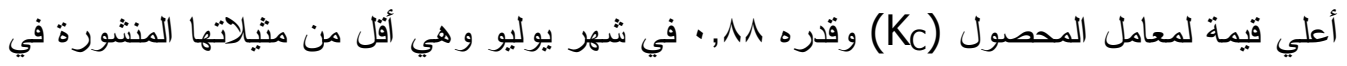

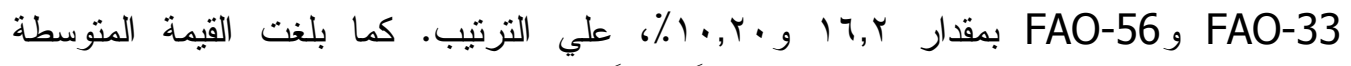

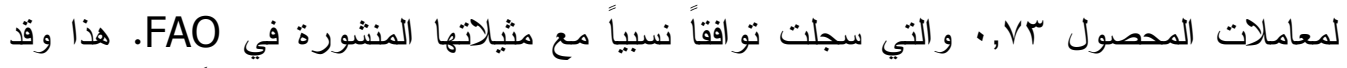

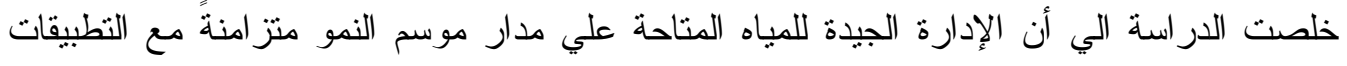

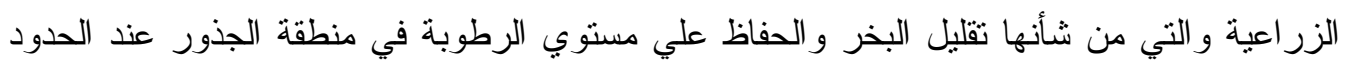
المناسبة والمسموح بها لنمو النبات بصورة صحية وكذللك التقدير الدقيق للإحتياجات المائية للنبات

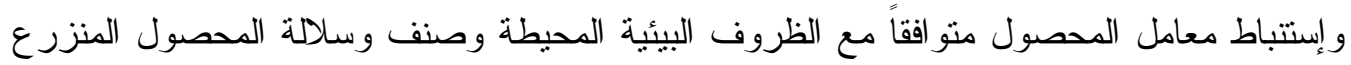

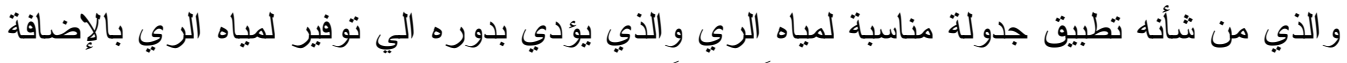
الي معظمة المحصول و من ثم تحقيق عائداً مناسباً. 